\title{
Aesthetics of Building Material in the Buildings of Architect Augusts Malvess
}

\author{
Jānis Krastiňš, Riga Technical University
}

\begin{abstract}
Architect Augusts Malvess is well-known in history of Latvian architecture in general and in architecture education in Latvia in particular, but so far not all of the buildings designed by him have been identified and architecture of his creations has not been evaluated in the context of artistically stylistic and theoretical principles. The article presents the analyses of the architect's specific creative approach based on the use of various building materials with the purpose of achieving artistic expression. Several until now unknown, but significant facts in the history of Latvian architecture have been explored.
\end{abstract}

Keywords -20 th century architecture, A. Malvess, architectural stylistics.

\section{INTRODUCTION}

Architect Augusts Malvess (1878-1951) has made a significant contribution to the legacy of Latvian architecture, but until now, he was known mostly as an educator and building material specialist. In 1919, he was one of the founders of the Faculty of Architecture of the University of Latvia and worked there until his death. From 1928 to 1930, he was the Dean of the Faculty of Architecture. In 1939, he became an Extraordinary Professor, but in 1944 - Head of the Department. The main subject that he supervised at the university was on building structures and building materials. Maybe this is why his students did not know that many buildings in Riga and elsewhere had been constructed to his projects $[1,98]$. Only the building incorrectly named as Vidzeme III Credit Union, which obviously meant the building of the Credit Union of Riga Industrialists and Craftsmen at Blaumaña iela $5 a$, as well as in many unspecified private buildings have been listed as his contribution to the building stock of Riga in one of the few publications dedicated to him in the interwar period in the Latvian Dictionary of Conservation [2]. The total number of recognized buildings constructed to his projects in Riga is at least 25 .

A. Malvess started his creative activity at the construction bureau of architect Konstantīns Pēkšēns (1859-1928) after the graduation from Riga Polytechnical Institute in 1906, but in 1909, he opened his own office. Which buildings had been constructed to the projects developed there ,was found only in the 1970's when research on Riga Art Nouveau architecture began. The list of buildings designed by A. Malvess was published in 1995 [1, 105], but it mainly included the buildings that had been built in Riga after 1909. Recently, the scope of work of this architect has been explored in more detail. A. Malves's creative activity at K. Pēkšēns' office, as well as his creations outside Riga are ana- lysed in this article, particular attention being paid to means of artistic expression used in building architecture.

\section{Buildings by A. Malvess in Riga}

The most productive phase of A. Malves's creative activity coincided with the culmination of Art Nouveau. In 1909, when Malvess began to work independently, he designed the apartment houses at Stabu iela 99 (Figs. 1 and 2) and Katrīnas dambis 20 (Fig. 3), and the following year, i.e. in 1910, the apartment houses with shops at Alūksnes iela 5 (Fig. 4) and Krišjāṇa Valdemāra iela 18 (Fig. 5). Surfaces of rusticated travertine create artistic accents in the façades of all these buildings, and to make the contrast stronger, at Katrīnas dambis 20 and Alūksnes iela 5 they are combined with bands of red brick. The façades at Stabu iela 99 and Krišjāṇa Valdemāra iela 18 also include some modest stylised ethnographic patterns created by varying plaster of different textures, as well as inserts of coloured ceramic tiles. In the portal at Stabu iela 99 small ceramic tiles are set in a sunshaped ornament, while at Krišjāña Valdemāra iela 18 the frieze running between the second- and third-floor windows is designed to look like a belt of a Latvian national costume.

Stylistics of these buildings fits in the National Romanticism trend of Art Nouveau, which had flourished in Riga architecture since 1905 and came to a sudden stop in 1911. The rapid decline of National Romanticism is due to the dynamics of the aesthetic views in the early 20 th century. It was also fuelled by the art criticism, which often was not sparing of ironic or even reviling pamphlets about the innovations of the time. Also, facade finish in the subsequent works of A. Malvess became more restrained, mainly using only traditional plaster.

Lasting contribution of Art Nouveau in general and of National Romanticism in particular to the art of its time was that it promoted the awareness of the importance of building materials. Architect Eižens Laube, one of the promoters of National Romanticism, expressed this in his theoretical views: "Besides the purpose of the building, the material of which it has been built and the material handling technique is of significant importance. [..] To implement a convenient building into a structure, each material requires a special construction type and special treatment technique. [..] Plaster has so far been used as an imitation of stone. Everyone understands how wrong it is. Looking at the nature of the plaster, we see that it is like a skin, a cover that closely adheres to the masonry and projections from it. Taking into account such peculiarity of the plaster, it naturally needs to 

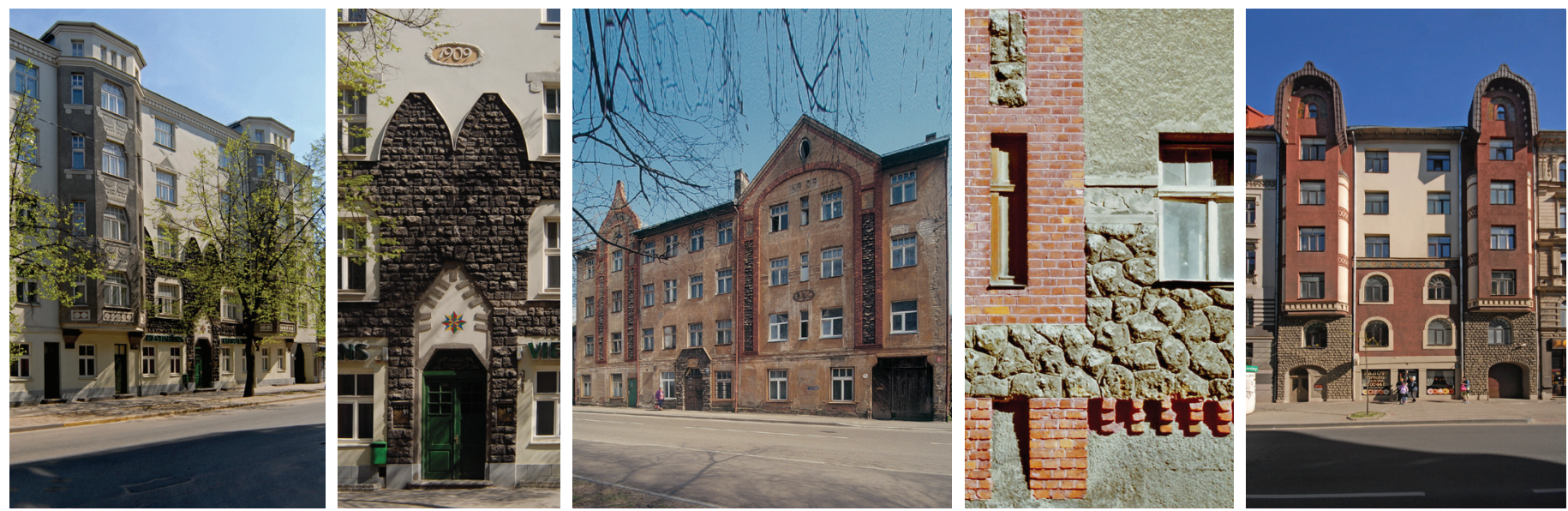

Fig. 1. Rīga. Apartment Fig. 2. Rīga. Apartment Fig. 3. Rīga. Apartment house at Kahouse at Stabu iela 99. 1909. house at Stabu iela 99. trīnas dambis 20. 1909. Augusts MalAugusts Malvess.

Fig. 4. Rīga. Apartment Fig. 5. Rīga. Apartment house at house at Alūksnes iela 5. Krišjāna Valdemāra iela 18. 1910. 1910. Augusts Malvess. Augusts Malvess. Façade fragment.

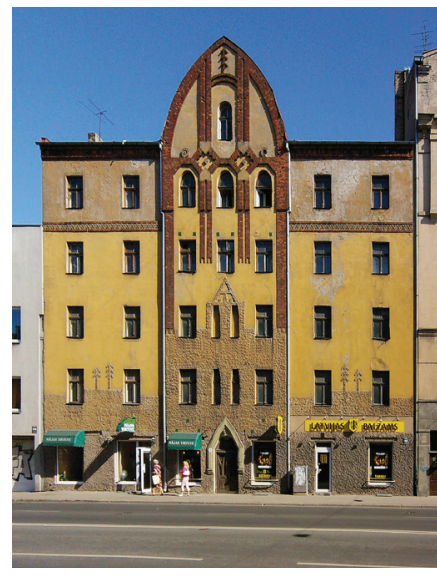

Fig. 6. Rīga. Apartment house with Fig. 7. Rīga. Apartment house with shops shops at Brīvības iela 192. 1907. Kon- at Krišjāṇa Barona iela 40. 1907. Konstantīns Pēkšēns, Augusts Malvess.

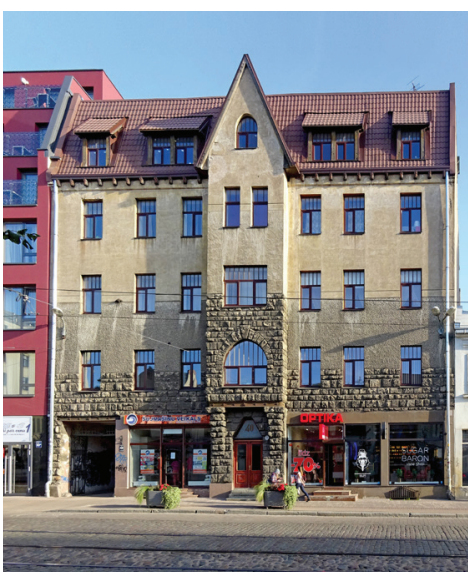

stantīns Pēkšēns, Augusts Malvess.
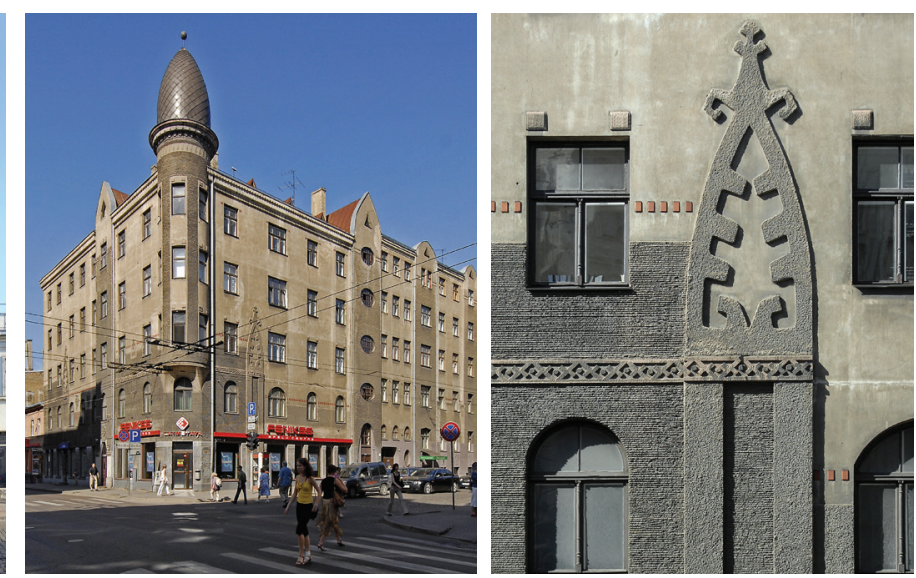

Fig. 8. Rīga. Apartment house with Fig. 9. Rīga. Apartment house with shops at Gertrūdes iela 46. 1908. Kon- shops at Gertrūdes iela 46. 1908. Konstantīns Pēkšēns, Augusts Malvess. stantīns P’ēkšēns, Augusts Malvess. Façade fragment. be treated as an area. The most useful way is brushing, making coarse or fine textures, and shaping ornamental patterns" [3, 147].

A. Malvess apparently had mastered the skills of using the variations of different decorative materials to obtain an artistic effect already during the first steps of his professional activity at K. Pēkšēns' workshop. At least four or five buildings constructed between 1906 and 1909 to the projects signed by K. Pēkšēns clearly indicate the creative 'language' of A. Malvess. These are apartment houses at Brīvības iela 192 (1907, Fig. 6), Sapieru iela 1a (1907), Krišjāṇa Barona iela 40 (1907, Fig. 7), and Ģertrūdes iela 46 (1908, Figs. 8 and 9), as well as the Riga II Credit Savings Union Bank with apartments and shops at Brīvības Street 46 (1907). The juxtaposition of various unusual shapes, textures and colour combinations have been actively used in the facade of these buildings. Metal structural elements - lintels above the gateway and entrance portal - are exposed in the façade at Krišjāña Barona iela 40. The manner of the graphical rendering of the projects of these buildings is analogous to that of the projects later executed at A. Malvess' own office.

The facade at Brīvības iela 46 (Figs. 10 and 12) shaped in Art Nouveau aesthetics reflects to a certain extent both the architectural idiom of Latvian National Romanticism that was popular at the time of designing the house and the expression of the so-called Homeland style (Heimatstil), which was rife in the Art Nouveau architecture of Germany. However, the most recognizable component of the artistic composition is the picturesque vertical red brick bands. The verticality is even more emphasised by spandrels: in bay windows they look like coffered bands, while in the right wing facing Dzirnavu iela they are filled with modest ornamental reliefs.

Between 2013 and 2015, the building underwent complete renovation when floors and ceilings were also replaced. The plan 


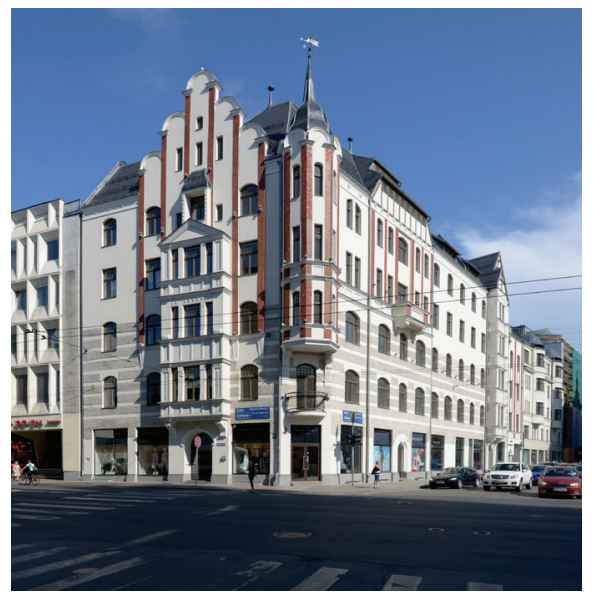

Fig. 10. Rīga. Building of Riga II Credit Savings Union Bank with apartments and shops at Brīvības iela 46. 1907. Konstantīns Pēkšēns, Augusts Malvess.

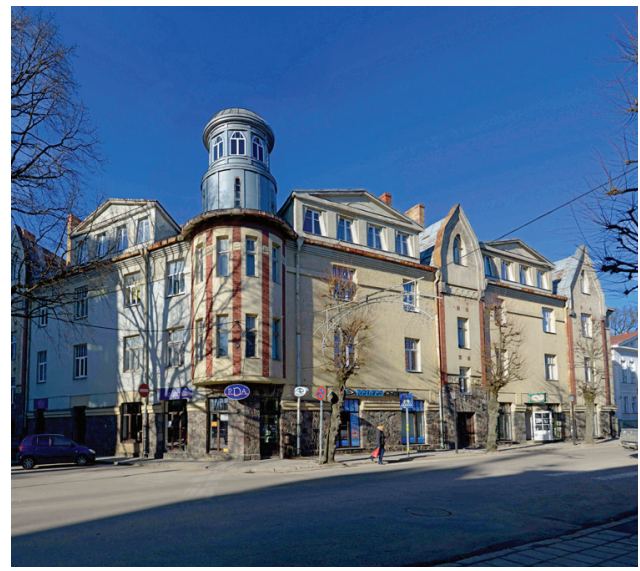

Fig. 14. Cēsis. Apartment house with shops at Raunas iela 10. 1911. Augusts Malvess.
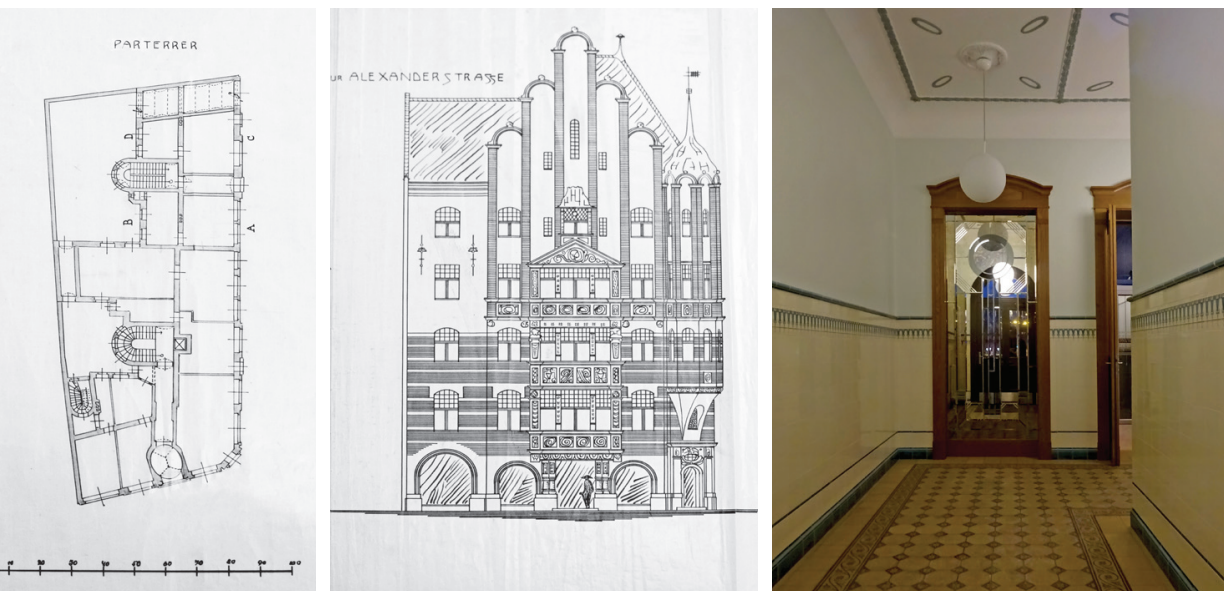

Fig. 11. Rīga. Building of Riga II Credit Savings Union Bank with apartments and shops at Brīvības iela 46. 1907. Konstantīns Pēkšēns, Augusts Malvess. Plan [4].
Fig. 12. Rīga. Building of Riga II Credit Savings Union Bank with apartments and shops at Brīvības iela 46. 1907. Konstantīns Pēkšēns, Augusts Malvess. Elevation towards Brīivības iela [4]
Fig. 13. Rīga. Building of Riga II Credit Savings Union Bank with apartments and shops at Brīvības iela 46. 1907. Konstantīns Pēkšēns, Augusts Malvess. A new hallway (2016)

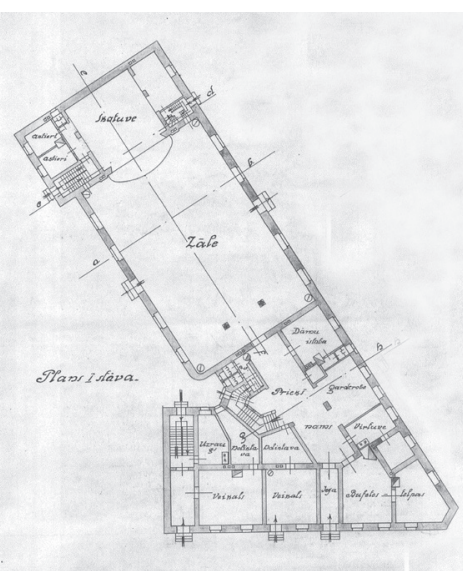

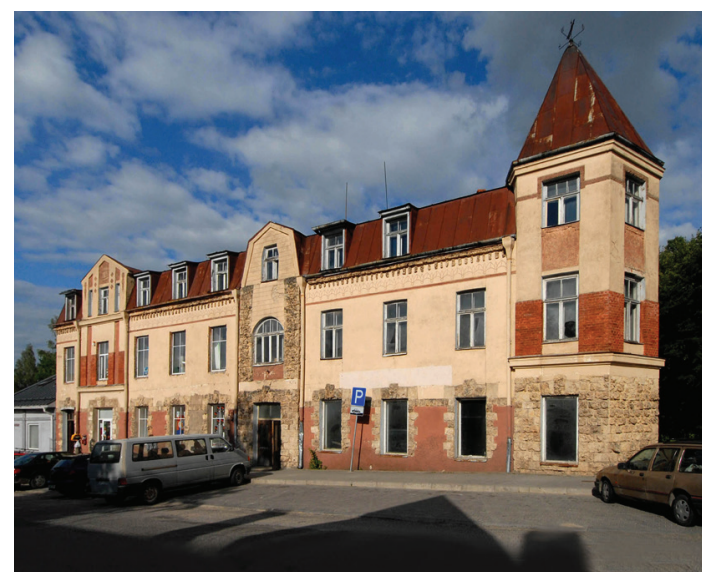

Fig. 15. Rauna. Agricultural Society House at Rīgas iela 1. 1909. Augusts Malvess.
Fig. 16. Rauna. Agricultural Society House at Rīgas iela 1. 1909. Augusts Malvess. Layout of the ground floor [8]. of the ground floor (Fig. 11) was changed, doing away with the entrance hall and hallway from Brīvības iela to the main staircase. The floor and wall finish in these rooms, which included characteristic Art Nouveau ceramic tiles, was destroyed. A new entrance hall from Dzirnavu iela was built. Its finish imitates the tiling of the destroyed rooms (Fig. 13).

\section{Buildings by A. Malvess Outside Riga}

Architecture of most of the schools, community houses and residential buildings that have been created outside Riga to the projects by A. Malvess attracts attention due to the picturesque colourful texture and tonality of various finishing materials. Only the Cēsis Society House at Raunas iela 12, built in 1914, restored from 1921 to 1924 [5] and nowadays integrated into the building of the Vidzeme Concert Hall, as well as the Community House in
Jaunjelgava, Jelgavas iela 31, which was built in 1912, are shaped in the manner of restrained Neo-classicism.

Next to the Cēsis Society House, at Raunas iela 10, there is an apartment house with shops (Fig. 14) that belonged to contractor Krišjānis Plaucinsš. It was built to the design by architect A. Malvess [6] in 1911 [7]. Each floor above the ground floor houses four vast apartments with all amenities. In the façade's architecture the expressive stylistic approach of the National Romanticism can be traced: the ground floor is coated with cut stone, whereas the dormer windows have sloping sides. The architect's creative language is characterized by vertical red brick bands, which are rhythmically aligned on the cylindrical corner bay window and frame the edges of the shallow avant-corps. The façades are practically void of any ornaments.

One of the artistically most expressive works by A. Malvess is Rauna Agricultural Society House in Rauna, at Rìgas iela 1 

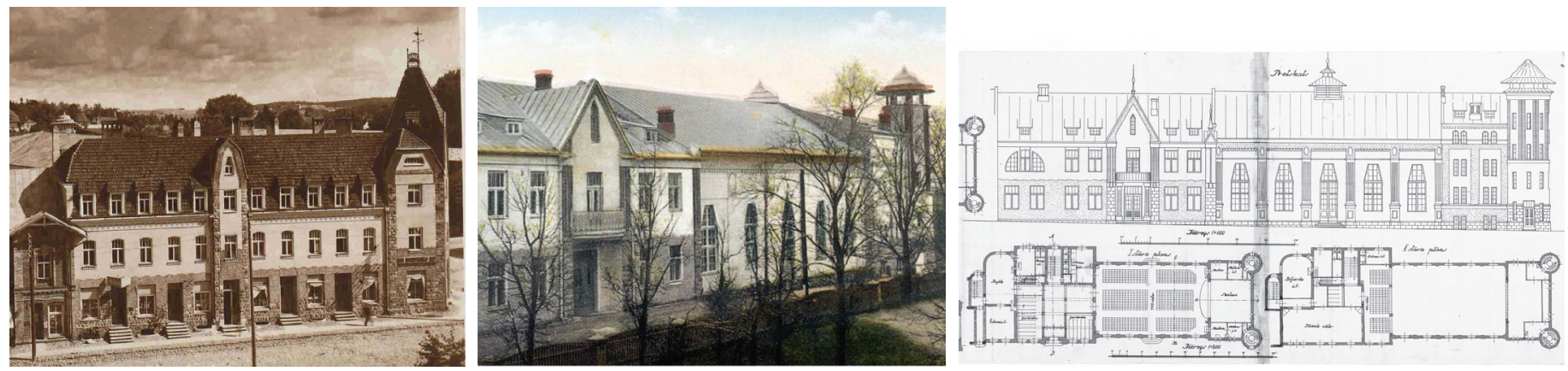

Fig. 17. Smiltene. Agricultural Society House (not preserved). 1908-1913. Augusts Malvess [9].
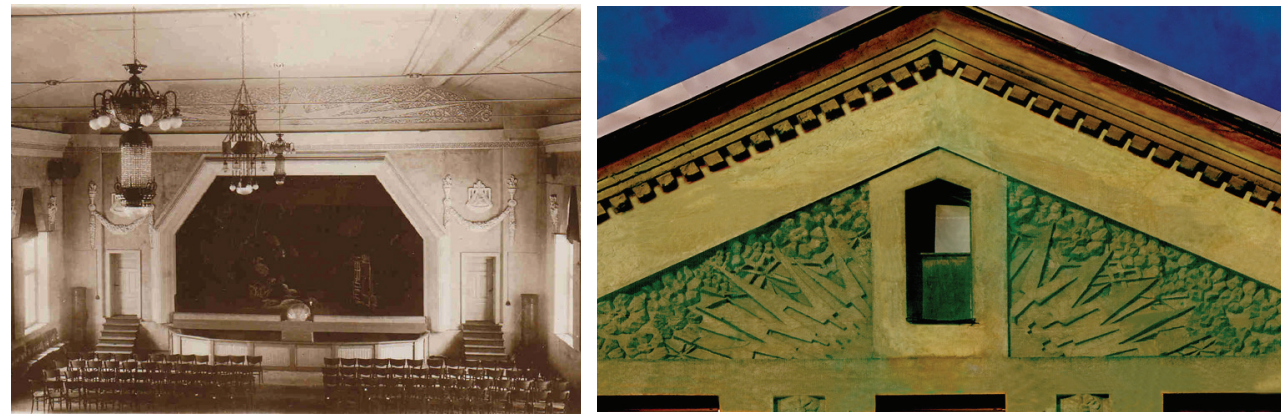

Fig. 20. Smiltene. The wing with the hall in the present Pils iela. The hall layout (photograph by Arnolds Oskars Pirro) [9].

Fig. 21. Riga. Apartment House with shops at Duntes iela 48. 1912. Augusts Malvess. Detail of the façade.

Fig. 18. Smiltene. The wing with the hall in the Fig. 19. Smiltene. The wing with the hall in the present Pils iela. present Pils iela (postcard, early 20th century) [9]. Design of the extension [13].
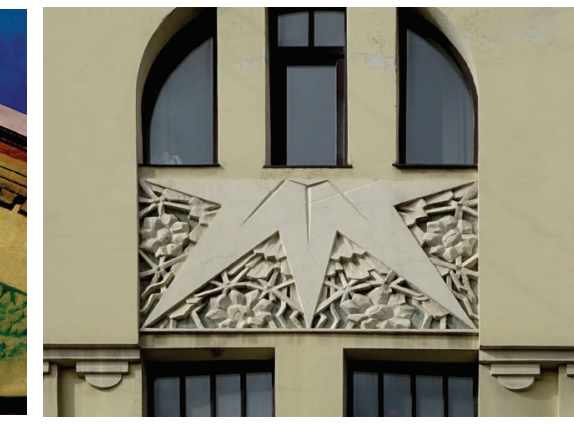

Fig. 22. Riga. Apartment House with shops at
Tallinas iela 92. 1912. Augusts Malvess. Detail of the façade.
(1909, Figs. 15 and 16). The elegantly balanced compositions of the building's picturesque façades feature interplay of various textures of plaster, as well as red brick surfaces and rustication in local travertine. A string of masonry dentils stretches under the cornice, but below it - an ornamental frieze in sgraffito technique with fine yet assertively robust lines. Artistically, both bands are in perfect harmony. The building is located directly between the ruins of Rauna's medieval castle and Rauna's church and in terms of its cultural and historic significance it is an absolutely equivalent member of the chain with its both neighbours - architectural monuments of highest rank.

Significant place in the history of Latvian culture has Smiltene-Palsmane-Aumeistere-Gaujene Agricultural Society House (Fig. 17), although it had been damaged during Wold War II and was later demolished. It was located in the very centre of Smiltene, on the corner of the present Baznīcas laukums and Pils iela. In 1934, architect Jānis Rutmanis selected it as one of the three illustrations, which depict the entire architecture of the early 20th century in Latvia [10].

In the beginning of the 20th century, the Agricultural Society owned a building erected in 1893 (has not survived, either). It was facing the present Baznīcas laukums. A commercial building of the Agricultural Society was constructed next to it, on the corner of Baznīcas laukums and Pils iela, and later was extended with a wing for an assembly hall at Pils iela. Starting with 1909, the corner building was rented to the Smiltene Consumers' Association, and it housed several shops, a hairdressing saloon, a bak- ery and a bookstore [11]. The history of both buildings, as well as the spirit of the times is well reflected in a newspaper article by an unknown author who signed it with an initial 'A': "Since the border of the association's plot was right at the crossroads, the members agreed to first erect a commercial building, which would then help from its profits to accomplish the construction of a larger hall. And, indeed, on 3 June 1908, the Association laid the foundations of its second three-storey house (next to the first), the designer of which is an architect from Riga - Pēkšēns, and which together with its wings cost 31000 roubles. But already during the construction of this big house architect Malvess was asked to draw a plan for the assembly rooms. [..] The local Savings' Bank as well as the Music and Singing Society came up with money for this noble enterprise, calculated at 36000 roubles. A few members inscribed the amounts of their donations for this assembly hall in the so-called Golden Registry. On 15 May 1912, the corner stone was laid for the hall, under which a memorial message was placed, and on 30 June 1913, the hall was inaugurated with a grand event - a play by Aspazija 'Vaidelote"' [12].

The dates mentioned in the article are apparently accurate; however, the statement about the architect of the 'second three-storey house' calls for a correction. The project was indeed designed by the construction bureau of K. Pēkšēns, but the author of the design quite definitely was A. Malvess. He is mentioned as the architect of the house also by J. Rutmanis [10], besides, the principles of the façade composition, architectural elements, 

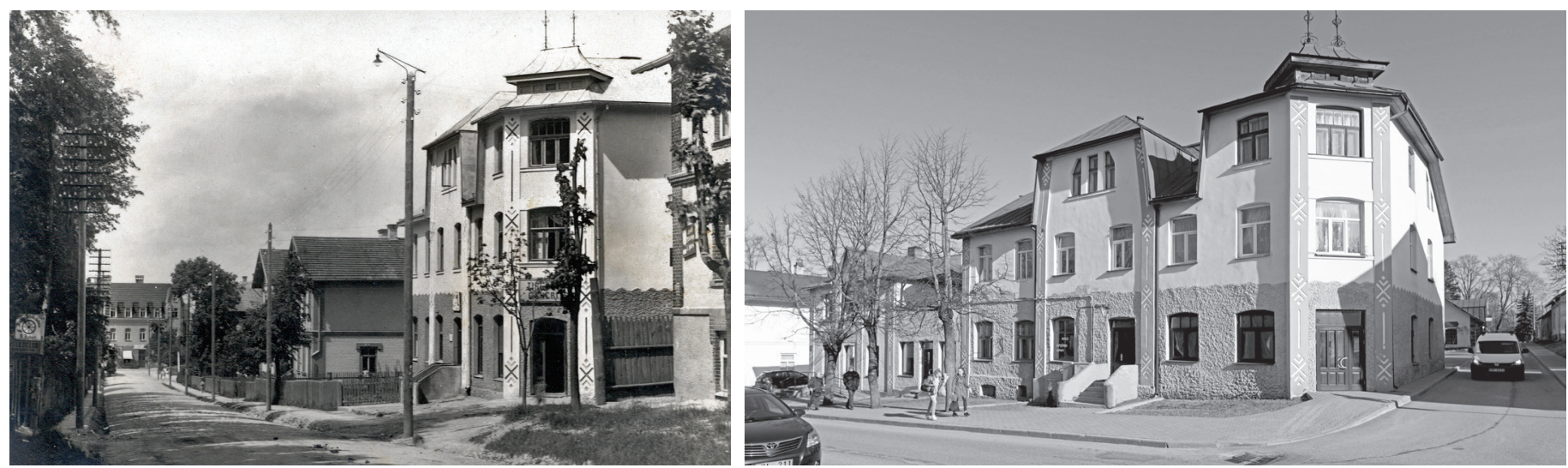

Fig. 23. Smiltene. Apartment house with shops at Dārza iela 13. 1912. Augusts Malvess. Photo from the early 20th century [14]. (At the end of the street - the

Fig. 24. Smiltene. Apartment house with shops at Dārza iela 13. Contemporary photo. wing of the Agricultural Society House at the present Pils iela).

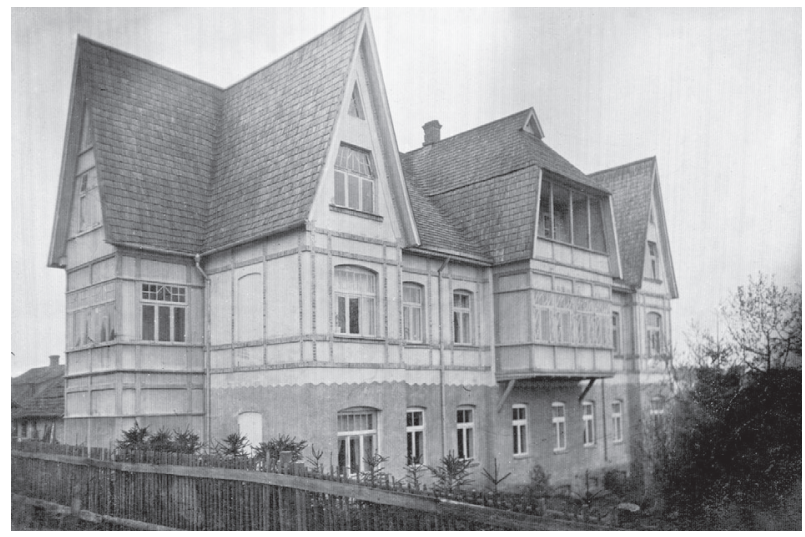

Fig. 25. Smiltene. Apartment house at Blaumana iela 2. 1913 (?). Augusts Malvess. Exterior view in 1920s [14].

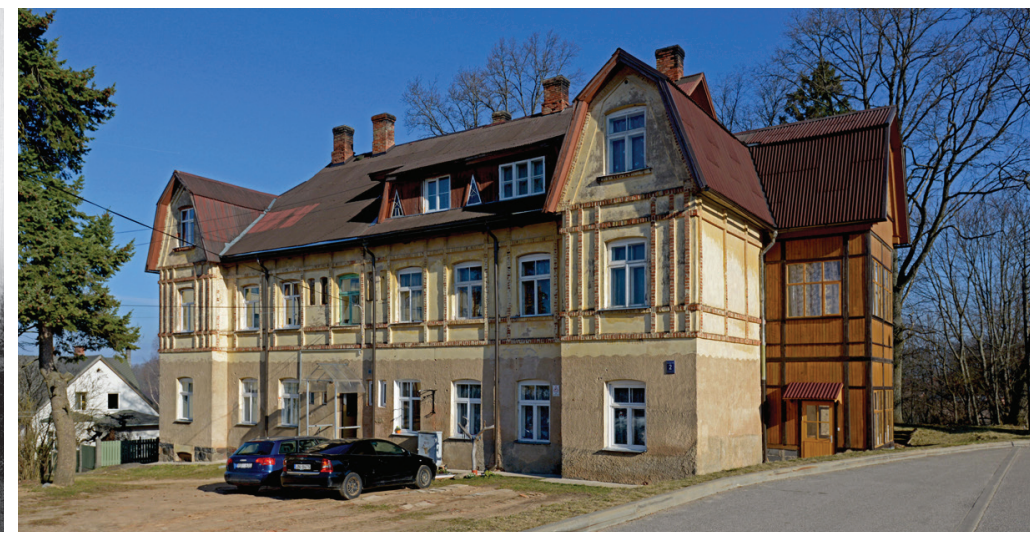

Fig. 26. Smiltene. Apartment house at Blaumaņa iela 2. 1913 (?). Augusts Malvess. Exterior view nowadays.

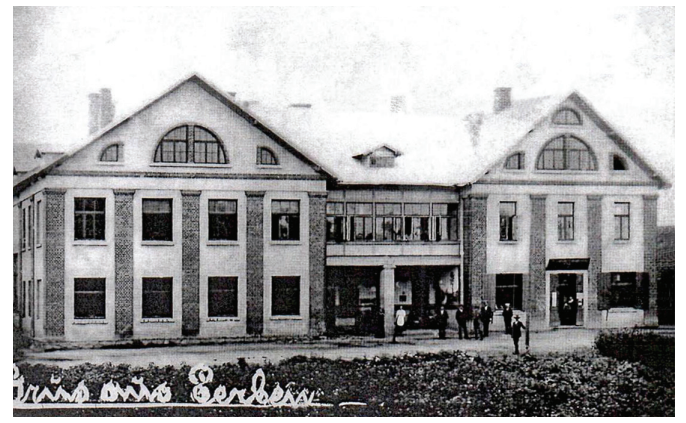

Fig. 27. Dzērbene. Community house (not preserved). Early 20th century. Augusts Malvess [17].

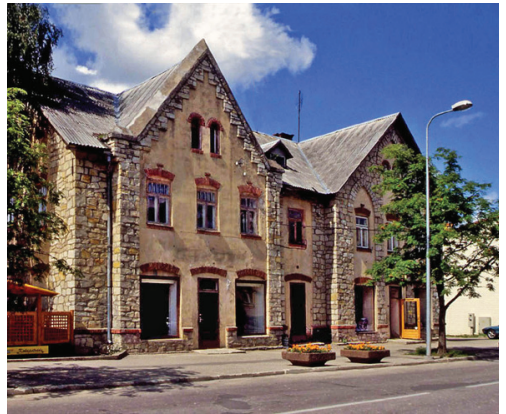

Fig. 28. Alūksne. Anna Agricultural Society House 'Economy' in Alūksne, at Lielā Ezera iela 4. 1912. Augusts Malvess (?)

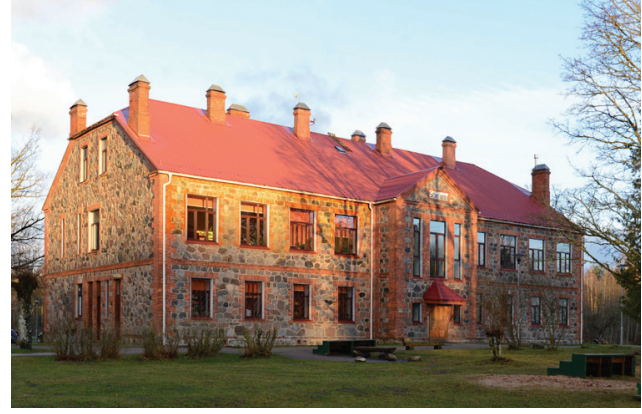

Fig. 29. Sēja. Parish School. 1914-1922. Augusts Malvess. finishing details and applied construction materials are almost analogous to the Rauna Agricultural Society House.

The wing, which was built in 1912-1913 at the present Pils iela (Figs. 18 and 19) housed a hall with a stage and 733 seats in the stalls. A smaller hall and a billiard room were on the first floor. It was probably the largest auditorium in Latvia outside Riga. Impressive were the finishing details blending National Romanti- cisms and Neoclassicism. The hall was lit by three modern chandeliers at night, while the ceiling near the stage was decorated by an exquisite relief featuring an edged star-shaped ornament. All this can be seen in a photograph taken in 1925 by Smiltene photographer Arnolds Oskars Pirro (Fig. 20).

Architect Malvess created reliefs similar to the ones found in Smiltene in the façades of the apartment houses with shops 

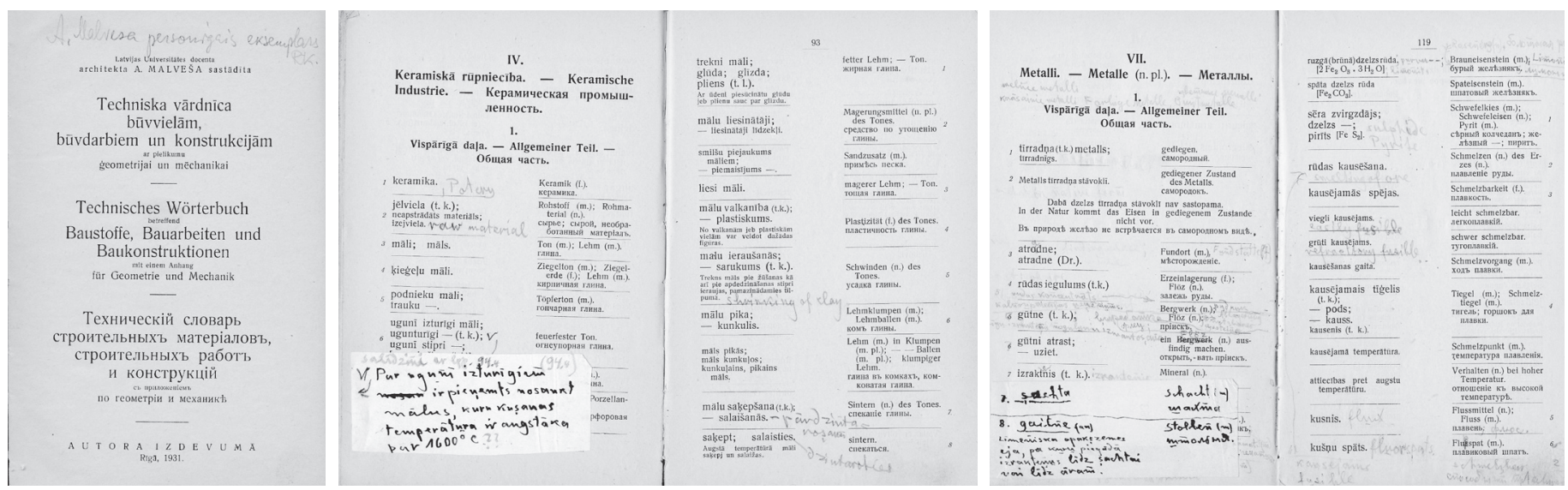

Fig. 30. Technical Dictionary of Building Materials, Construction works and Structures. The tittle list and two facing pages [20].

in Riga, at Duntes iela 48, and Tallinas iela 92, also built in 1912 (Figs. 21 and.22). The artistic expression of these details can be considered as a direct anticipation of the Art Deco aesthetics flourishing in the 1920s. It is also present in the architecture of the residential building at Dārza iela 13 in Smiltene (Figs. 23 and 24), which also reflects the vocabulary of National Romanticism. Several lesenes adorned with ethnographic ornaments resembling the belt of a national costume, rise in the full height of the façade. The building was built in 1912 by Dāvis Nodievs - a well-known public figure in Smiltene [14]. It is very likely that the architect of this house was also A. Malvess.

A little later D. Nodievs built an apartment house at Blaumaņa iela 2 [14]. Its ground floor façade, just like at Dārza iela 13, is finished with a plaster of slightly darker and rougher texture (Figs. 25 and 26). In a similar manner - with an undulating line - the transition to a smoother surface and a lighter colouring of the façade of upper floors is achieved. On the first floor, the wall is divided into separate squares by red brick bands. In this case, the brick bands create an impression of a half-timber structure. The polygonal contour of the gables resembles the Rauna and Smiltene Agricultural Society Houses and Plaucinšs' House in Cēsis. Thus, the answer to the question about the potential architect of the building seems to be answered.

Not only community houses in Jaunjelgava, Cēsis, Rauna and Smiltene, but also in Sigulda, Dzērbene [2] and possibly also in Alūksne are constructed to the projects by A. Malvess. The Sigulda Association 'Vidzeme Switzerland' house, built in 1911, was burned down by the Russian troops in 1917 [16]. The Dzērbene community house (Fig. 27), like the house in Smiltene, perished in the Second World War. This building of impressive size was shaped in freely stylized classical forms, but pilasters in both asymmetric avant-corps were laid of red bricks.

Anna Agricultural Society House 'Economy' in Alūksne, at Lielā Ezera iela 4 (Fig. 28) was built in 1912. The architecture of the building has the same decoration and material utilization techniques that are used in the buildings by A. Malvess. Its façade is a combination of plaster and rock-faced stonework, whereas the aperture lintels are made of red brick. The building to a certain extent resembles the barns characteristic of northern Vidzeme. Yet, the seemingly symmetrical structure is asymmetrical: each of the markedly protruded avant-corps, though equal in size, has a different composition of the architectural finish. On the left side, the masonry wall highlights the contour of the avant-corps, but on the right - creates a stylized arcade. A true symphony of splintered fieldstone masonry with red brick accents is Sejja Parish School (Fig. 29). The construction started in 1914, and was completed in 1922 [18].

\section{Scientific and Theoretical Activities}

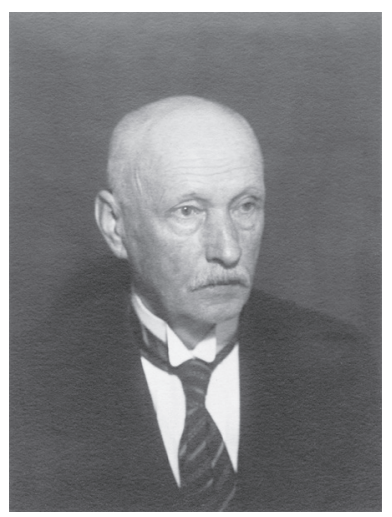

Fig. 31. Augusts Malvess in late 1930 s.
After the First World War, when the professional life of the architect was mainly pedagogical and scientific work, natural consequence of his creative experience was a focus on building materials. He created an impressive collection of various building materials that was used in the learning process. True, one of the first publications was dedicated to the memory of architect Jānis Frīdrihs Baumanis [19]. A. Malvess was the first who paid attention to the role of the first professional Latvian architect's heritage in the cityscape of Riga.

The most significant theoretical work of A. Malvess - 'Technical Dictionary of Building Materials, Construction works and Structures' in Latvian, German and Russian [20] - was published in 1931. It was an important contribution to the terminology of the Latvian language, which in many technical specialties has not yet been sufficiently developed. The architect never stopped working in this field. He certainly intended to revise and supplement the dictionary, adding translations and explanations of terms in English too. This is evidenced in numerous notes and entries in the architect's personal copy of the dictionary (Fig. 30). 
Records were made in the 1930s and continued in the late 1940s. It can be precisely detected due to the entries made on the back side of the sheets of date-block and pasted on the pages of the dictionary. This dictionary was once 'appropriated', as written in a small cover letter by engineer Rūdolfs Knaps, and handed over to the then secretary of the Terminology Commission of the Latvian Academy of Sciences, later academician and chairman of the Terminology Commission, Valentīna Skujiņa in 1972. Then, this copy of the dictionary passed into the disposal of the author of this article in 2013.

One of the last salon photos of architect A. Malvess also has been preserved in the personal archives of the author of the article (Fig. 31). It was found in the middle of the 1970s in a wet wood cutter located in the courtyard of a small wooden cottage at Kemeru iela, where the architect's last residence was. Photographs, for a long time, smelled of natural mould.

\section{CONCLUSion}

Contribution of architect Augusts Malvess to the architecture of Latvia has so far been recognized fragmentary and primarily from a statistical viewpoint. His creative legacy is more voluminous than fixed in publications devoted to his creative work so far. Most of the buildings constructed to his projects implemented a precisely formulated creative concept based on the use of the materials with the intention to achieve artistic expression. His architecture is organically linked to his theoretical research topic. The heritage of A. Malvess is a sample of synthesis of architectural practice and theory.

\section{REMARK}

All photographs, unless indicated otherwise - by the author of the article.

\section{REFERENCES}

1. Krauklis, O., Krastiṇš, J. Augusts Malvess (1879-1951). Latvijas arhitektūras meistari (Rīgas Tehniskās universitātes Arhitektūras fakultāte). Rīga: Zvaigzne ABC. 286 lpp.

2. Malvess, Augusts. Latviešu konversācijas vārdnīca : Trīspadsmitais sējums (A. Švābe, A. Būmanis, K. Dišlērs, red.). Rīga: Grāmatu apgādniecība A. Gulbis, 1935-1936. 25558. sleja.

3. Laube, E. Par būvniecības stilu. Zalktis : Rakstu krājums mākslai un kritikai, 1908, Nr. 4, 145.-148. lpp.

4. Latvian State Historical Archives (LSHA), fund 2761, descroptions 3, case 2306, p. 22.

5. LSHA, fund 6343, description 6, case 17.

6. According to information provided in 1980 by architect Leons Plauciņš, son of K. Plaucinšs.

7. LSHA, fund 10 , description 4, case 892, page 304

8. LSHA, fund 6343, description 7, case 253 .

9. Historical photos from the local history archive of the Smiltene District Library.

10. Rutmanis, J. Latviešu arhitektūra 19. un 20. gs. Mākslas vēsture : I sēj. . Arhitektūra un tēlniecība (V. Purvīša visp. red.). Rīga: Grāmatu Draugs, 1934. 1. sēj., 256. lpp.

11. Liuke, A. Ceḷojums laikā: manas bibliotēkas ēkas vēsture [tiešsaiste 24.06.2017]. http://biblioteka.valka.lv/wp-content/biblioteka/celojumsSmiltene.pdf
12. Smiltenes-Palsmanes-Aumeisteru-Gaujenes Lauksaimniecības biedrība. Kopdarbība, 1923, 6. oktobris, 627.-628. lpp.

13. LVVA, fund 6343 , description 7 , case 119 .

14. Zušmanis, J. Smiltene: laiki un likteņi. Smiltene: Smiltenes TV, 2004. 217. 1pp.

15. Photo from the family archive of Kaspars Nodievs.

16. Vidzemes Šveice 1880-1930. Siguldas Ziņas, 1930, 22. nov. (Nr. 22), 1.-3. lpp.

17. Materials from the local history archive of Dzērbene People's House

18. Vēsture [tiešsaiste]. Sējas skola [skatīts 11.11.2017]. http://sejasskola.lv/ par-skolu/vesture/

19. Malvess, A. Arhitekts Jānis Baumanis (1834-1891). Ilustrēts Žurnāls : Mākslas un rakstniecības mēnešraksts, 1925, Nr. 4, 106.-113. lpp.

20. Malvess, A. Tehniskā vārdnīca būvvielām, būvdarbiem un konstrukcijām ar pielikumu geometrijai un mehānikai = Technisches Technisches Wörterbuch betreffend Baustoffe, Bauarbeiten und Baukonstruktionen mit einem Anhang für Geometrie und Mechanik = Технический словарь строительных матералов, строительных работ и конструкиий с приложением по геометрии и механике. Rīga: Autora izdevums, 1931. 688 lpp.

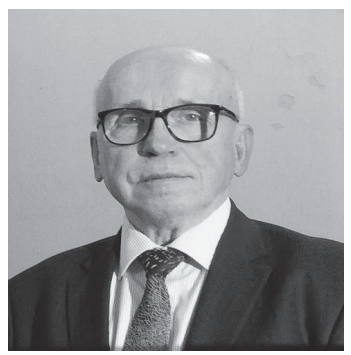

Jānis Krastiṇš (1943), Dr. habil. arch. (1991), is a full member of the Latvian Academy of Sciences (1994, holder of the Great Medal 1998), Professor at Riga Technical University, member of the Latvian Association of Architects (1970). He has designed numerous public and residential buildings and carried out investigations of historic structures. He is the author of more than 690 scientific works published in Austria, Belgium, Czech Republic, Denmark, Iceland, Italy, Estonia, Finland, France, Germany, Latvia, Lithuania, the Netherlands, Norway, Poland, Russia, Spain, Sweden, Turkey, United Kingdom and the United States of America, including 27 books on various aspects of history and theory of architecture.

\section{Contact Data}

\section{Jānis Krastiňš}

Riga Technical University

Faculty of Architecture

Address: 6 Ķīpsalas St., Riga, LV-1048, Latvia

E-mail: Janis.Krastins_1@rtu.lv 